\title{
EFFECT OF IMMERSION TIME TO MECHANICAL STRENGTH OF POLYVINYL ALCOHOL- HYDROXY APATITE COMPOSITE AS BIODEGRADABLE BONE PLATE
}

\author{
(PENGARUH WAKTU PERENDAMAN TERHADAP KEKUATAN MEKANIS \\ KOMPOSIT POLIVINIL ALKOHOL-HIDROKSI APATIT SEBAGAI \\ FIKSASI FRAKTUR TULANG)
}

\author{
Mochammad Taha Ma'ruf*, Widowati Siswomihardjo**, Marsetyawan Heparis Nur Ekanda Soesatyo***, \\ Alva Edy Tontowi***** \\ *Faculty of Dentistry, Mahasaraswati University, Denpasar \\ E-mail: tahamaaruf@gmail.com) \\ **Faculty of Dentistry, Gadjah Mada University, Yogyakarta \\ E-mail: bundi.kunto@gmail.com) \\ ***Faculty of Medicine, Gadjah Mada University, Yogyakarta \\ E-mail: marshnes@yahoo.com) \\ ****Faculty of Engineering, Gadjah Mada University, Yogyakarta \\ E-mail: tontowi59@gmail.com)
}

\begin{abstract}
Polymer based material such as Poly-L-Lactic-Acid (PLLA) have been used for titanium substitution. However, the last research indicates that it was not an ideal material as bone fracture fixation device. It is a challenge to develop other materials as biodegradable bone plate for titanium substitution, such as polyvinyl alcohol (PVA). In this study, polyvinyl alcohol has composited with Hydroxy apatite (HA) and reinforced with catgut fiber. The aim of this study was to know the effect of immersion time to mechanical strength of PVA-HA composite with catgut reinforced as biodegradable bone plate after biodegradation test for 30 and 60 days. Specimens were prepared for tensile and bending strength tests, immersed in phosphate buffered saline (PBS) solution with pH 7.4 at $37^{\circ} \mathrm{C}$. Specimens were weighed before and after biodegradation test, tensile and bending test were done after removed for 30 and 60 days. The result showed that PVAHA composite reinforced with catgut fiber has stable mechanical strength after 30 and 60 days biodegradation process. The mechanical strength decreased in 30 and 60 days in all intervention groups, but it still has adequate mechanical strength as biodegradable bone plate. In conclusion, PVA-HA composite reinforced with catgut fiber can be developed as biodegradable bone plate replace titanium and other commercial bone plate.
\end{abstract}

Key words: biodegradable, fixation, fracture, polyvinyl alcohol, hydroxy apatite

\begin{abstract}
Abstrak
Penggunaan bahan polimer sebagai alat fiksasi yang dapat diserap tubuh seperti Poly-L-Lactic-Acid (PLLA) telah digunakan sebagai pengganti titanium, tetapi penelitian terakhir menunjukkan bahwa bahan ini bukan sebagai bahan yang ideal sebagai alat fiksasi fraktur tulang. Merupakan suatu tantangan untuk mengembangkan bahan polimer lain sebagai alat fiksasi yang dapat diserap tubuh sebagai pengganti titanium, seperti polivinil alkohol (PVA). Pada penelitian ini, polivinil alkohol dikompositkan dengan hidroksiapatit (HA) dengan anyaman serat catgut sebagai penguat. Tujuan penelitian ini adalah mengetahui pengaruh waktu perendaman terhadap kekuatan mekanis komposit PVA -HA sebagai fiksasi fraktur tulang setelah mengalami biodegradasi selama 30 dan 60 hari. Spesimen disiapkan untuk uji kekuatan tarik dan tekuk, direndam dalam larutan phosphate buffered saline (PBS) $\mathrm{pH} 7,4$ pada suhu $37{ }^{0} \mathrm{C}$. Spesimen ditimbang sebelum dan sesudah perendaman, dikeluarkan setelah periode 30 dan 60 hari dan dilakukan uji kekuatan tarik dan tekuk. Hasil penelitian menunjukkan bahwa komposit PVA-HA dengan anyaman serat catgut memiliki kekuatan mekanis yang stabil pada proses biodegradasi selama 30 dan 60 hari. Sebagai kesimpulan, komposit PVA-HA dengan anyaman serat catgut dapat dikembangkan sebagai alat fiksasi fraktur tulang pengganti titanium dan alat fiksasi yang bisa diserap tubuh komersial lainnya.
\end{abstract}

Kata kunci: biodegradasi, fiksasi, polivinil alkohol, hidroksiapatit 


\section{INTRODUCTION}

Fixation device to correct facial and jaw bone fracture (bone plate) used stiff and rigid material from metal such as titanium, titanium alloy or cobalt chrome. In addition to its advantage, titanium as fixation device has also advantage such as very high mechanical strength and stiffness, leads to mechanical stimulus continuously that cause bone atrophy under plate that causesbone growth disorder particularly in children. ${ }^{1}$ Other disadvantages include it will be easy to detect visually or palpable, screw loosening, sensitive to temperature ${ }^{2}$, infection and interference with radiation therapy and imaging. ${ }^{3}$ Further studies showed that material caused distribution of metal ion on regional lymph nodes and induced allergic reaction. ${ }^{3}$ Some of these factors might require secondary surgery to remove the titanium bone plate, so use of the polymer material as biodegradable bone plate begins to grow.

Polymer based material for biodegradable bone plate such as Poly-L-Lactic Acid (PLLA) had some disadvantages due to its high crystalline during degradation process. ${ }^{4}$ Lactic acid monomer released during degradation led to cellular response in implant site, which facilitated releasing chemical mediator such as prostaglandin $\left(\mathrm{PGE}_{2}\right)$ by fibroblast and macrophage as the cause of bone resorption. ${ }^{4}$ Thus, the development of other polymer materials that has good biocompatibility and has mechanical strength as biodegradable bone plate like polyvinyl alcohol (PVA) will be a challenge.

Polyvinyl alcohol (PVA) is used to replace damaged and infected body tissue because it has physico chemical characteristic particularly biotribological characteristic (smooth surface, friction and wear resistance). ${ }^{5,6}$ The material has good biocompatibility in some biomedical applications such as drug delivery, contact lenses, bone graft, wound dressing, and used widely in the management of articular cartilage problems. ${ }^{7,8}$ Unfortunately, PVA does not have sufficient mechanical strength as bone plate, so in this study PVA has composited with hydroxyapatite (HA) to increase its mechanical strength. Hydroxy apatite is bioactive, osteoconductive, and good biocompatible materials. ${ }^{9}$ To increase stiffness, PVA-HA composite is also added with catgut woven, an absorabable wound suture material. The material obtained from sheep intestine and has been used widely in medical field including orthopedic for the closure deep tissue, so it should not be removed.

The aim of this study was to investigate effect of immersion time to mechanical strength of polyvinyl alcohol-Hydroxy apatite composite as biodegra- dable bone plate after biodegradation process for 30 and 60 days. The result is expected for developing bio-degradable bone plate substitute titanium, so secondary surgery can be avoided.

\section{MATERIALS AND METHODS}

This study used PVA Mowiol grade 56-98 (Aldrich-Germany), a fully hydrolyzed (98.0-98.8 mol \%) with viscosity at 52.0-60.0 mPa-s. PVA composited with calcite hydroxy apatite obtained by synthesizing calcite $(\mathrm{CaCO} 3)$ powder with diammonium hydrogen phosphate solution (DHP, $\left(\mathrm{NH}_{4}\right)_{2}$ $\mathrm{HPO}_{4}$; Merck-Germany). In each specimen layer added with chromic catgut $2 / 0$ plait, with horizontal orientation, five layers in each specimen. PVA and calcite HA powder were weighed according to its ratio. PVA was dissolved in distilled water in comparison $7.5 \%(\mathrm{w} / \mathrm{v})$ using stirrer machine $\left(95^{\circ} \mathrm{C}\right.$, $600 \mathrm{rpm}, 30$ minutes). After PVA dissolved, calcite $\mathrm{HA}$ was added, stirred and heated $\left(60^{\circ} \mathrm{C}, 300 \mathrm{rpm}\right.$, 60 minute). In prepared mold with catgut plait (Figure 1a), lay up was done layer by layer (Figure $1 b)$. Each layer was heated using oven $\left(70^{\circ} \mathrm{C}, 15\right.$ minutes) until it reached the layer and thickness desired. Specimen was heated using oven $\left(70^{\circ} \mathrm{C}\right.$, 120 minutes), then it was removed from the mold (Figure 1c).

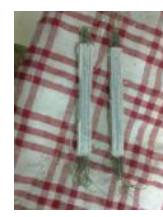

(a)

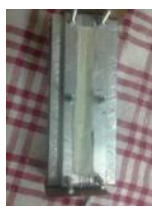

(c)

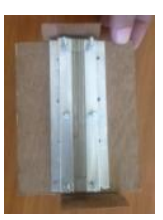

(b)

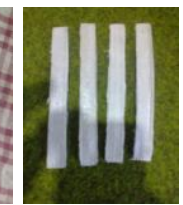

(d)
Figure 1. (a) Catgut fiber plait, (b) lay up process; (c) specimen with 5 catgut fiber layers; (d) specimens

There are four treatment groups $(\mathrm{P})$ with the variation of concentration PVA-HA with catgut fiber, that were $\mathrm{P} 1(80: 20)$; $\mathrm{P} 2(70: 30)$; $\mathrm{P} 3(60: 40)$; $\mathrm{P} 4$ (50:50) and $C(60: 40)$ without catgut fiber as control group. To identify mechanical strength of specimen during degradation process, biodegradation test was done by immersing specimen in phosphate-buffered saline (PBS) solution at ph 7.4 and incubated at $37^{\circ} \mathrm{C}$. In 30 and 60 days, specimen was weighed and performed for mechanical strength tests in- 
cluding tensile (ASTM D 638-99) ${ }^{10}$ and bending test (ASTM 790-99). ${ }^{11}$

\section{RESULTS}

Specimen was weighed before immersing in PBS solution and after 30 and 60 days period. Specimens was dried at $70^{\circ} \mathrm{C}$ for 2 hours, weighed and performed for mechanical strength tests.

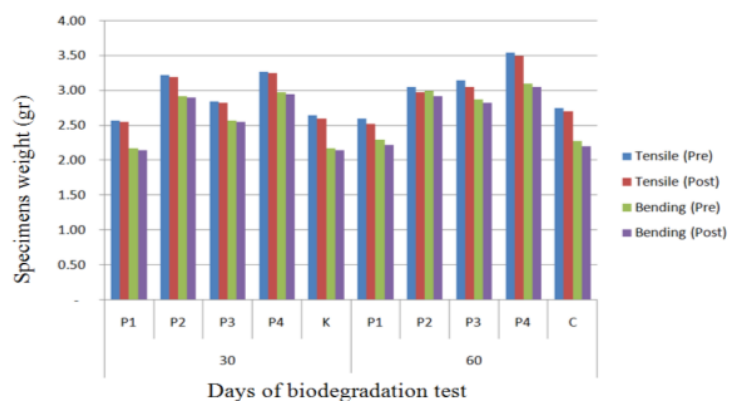

Figure 2. Weight loss of tensile and bending strength specimen after biodegradation test for 30 and 60 days

Table 1. Mean of tensile and bending tests after biodegradation test for 0,30 and 60 days

\begin{tabular}{|c|c|c|c|c|c|c|c|c|}
\hline \multirow{2}{*}{ Tests } & \multirow{2}{*}{$\mathrm{P}$} & \multirow{2}{*}{$\mathrm{n}$} & \multicolumn{6}{|c|}{ Days } \\
\hline & & & 0 & $p$ & 30 & $p$ & 60 & $p$ \\
\hline \multirow{10}{*}{ Tensile } & \multirow{2}{*}{ P1 } & \multirow{2}{*}{4} & 31.48 & & 28.57 & & 27.83 & \\
\hline & & & \pm 2.26 & & \pm 1.42 & & \pm 2.91 & \\
\hline & \multirow{2}{*}{$\mathrm{P} 2$} & \multirow{2}{*}{4} & 34.85 & & 34.59 & & 32.46 & \\
\hline & & & \pm 3.02 & & \pm 1.28 & & \pm 2.65 & \\
\hline & \multirow{2}{*}{ P3 } & \multirow[b]{2}{*}{4} & 43.06 & & 40.21 & & 39.88 & \\
\hline & & & \pm 0.18 & & \pm 0.67 & & \pm 1.13 & \\
\hline & \multirow{2}{*}{$\mathrm{P} 4$} & \multirow{2}{*}{4} & 37.96 & & 36.61 & & 35.99 & \\
\hline & & & \pm 1.36 & & \pm 1.28 & & \pm 1.58 & \\
\hline & \multirow{2}{*}{ K } & \multirow{2}{*}{4} & 14.04 & & 11.80 & & 10.78 & \\
\hline & & & \pm 1.32 & 0.001 & \pm 0.80 & 0.001 & \pm 1.49 & 0.001 \\
\hline \multirow{10}{*}{ Bending } & \multirow{2}{*}{ P1 } & \multirow{2}{*}{4} & 16.74 & & 11.95 & & 12.31 & \\
\hline & & & \pm 0.72 & & \pm 1.02 & & \pm 1.01 & \\
\hline & \multirow{2}{*}{$\mathrm{P} 2$} & \multirow{2}{*}{4} & 21.09 & & 19.87 & & 18.79 & \\
\hline & & & \pm 0.36 & & \pm 0.90 & & \pm 1.43 & \\
\hline & \multirow{2}{*}{ P3 } & \multirow{2}{*}{4} & 46.04 & & 34.56 & & 32.65 & \\
\hline & & & \pm 2.57 & & \pm 3.68 & & \pm 2.62 & \\
\hline & \multirow{2}{*}{ P4 } & \multirow{2}{*}{4} & 26.92 & & 23.83 & & 22.82 & \\
\hline & & & \pm 1.29 & & \pm 1.49 & & \pm 1.00 & \\
\hline & \multirow{2}{*}{ K } & \multirow{2}{*}{4} & 10.51 & & 10.00 & & 05.97 & \\
\hline & & & \pm 0.40 & 0.001 & \pm 0.27 & 0.001 & \pm 2.20 & 0.001 \\
\hline
\end{tabular}

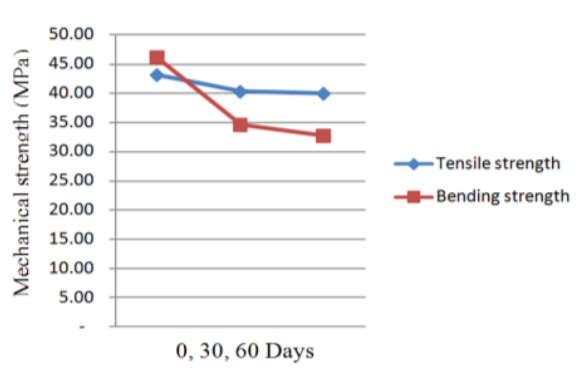

Figure 3. Decreasing in mechanical strength ofPVA-HA (60:40) composite with catgut fiber after biodegradetion tests at 0,30 and 60 days

\section{DISCUSSION}

Biodegradable bone plate should be semi rigid, stable characteristic and degradable perfectly without various complications. During degradation process, the material should have sufficient strength until bone healing process. A clinical study showed some advantages of biodegradable bone plate such as decreasing mechanical strength and late aseptic swelling, osteolysis change in implant site, imperfect bone healing in mandibular canal.

Biodegradation is defined as cutting polymer chain to be oligomer and then to monomer. Polymer degradation process occurring begun with water inserted polymer mass marked with specimen swellling, triggering chemically degradation of polymer and caused oligomer and monomer formed. Progressive degradation changes micro structure of the mass through forming porous as the exit of degradation product, which has acid-base function. Releasing oligomer and monomer finally cause decreasing in specimen weight. Figure 2 indicates decreasing in specimen weight in all treatment group and controls during biodegradation test for 30 and 60 days. The decreasing specimen weight indicated biodegradation process has begun in this period.

There are two ways of biodegradation, passive process with hydrolysis and active process with enzymatic process. Most of the polymer degraded by hydrolysis process, while biopolymer such as polysaccharide, gelatin and collagen are degraded in enzymatic way. Some factors can influence the speed of biodegradation are chemical bound type, $\mathrm{pH}$, copolymer composition and water content. Parameter used to monitor biodegradation besides the decreasing weight of specimen is a decreasing in mechanical strength.

Table 1 showed that control groups have mechanical strength below masseter muscle strength (tensile strength $14.04 \mathrm{Mpa}$; bending strength 10.51 Mpa) and there is a decreasing in mechanical strength far below standard at biodegradation test at 30 and 60 days. Table 1 also revealed that the addition of catgut fiber can be significantly increasing mechanical strength of PVA-HA composite ( $p$ $<0.05)$. Treatment group with PVA-HA (60:40) had the highest mechanical strength, and it was decreased in mechanical strength after biodegradation test for 30 and 60 days.

Based on result and discussion, it can be concluded that polyvinyl alcohol-hydroksiapatite composite with reinforced catgut fiber have sufficient mechanical strength after 30 and 60 days of biodegradation process. Polyvinyl alcohol hydroxyl apatite composite (60:40) with reinforced catgut 
fiber can be developed as biodegradable bone plate subs-titute titanium and other commercial biodegradable bone plate. It is suggested for further study related to performed plate and screw prototype, include biocompatibility in vitro and in vivo tests.

\section{ACKNOWLEDGMENT}

The authors are thank full to Department of Industrial and Mechanical Engineering Gadjah Mada University Yogyakarta, especially Bioceramics Laboratory for all support on the research.

\section{References}

1. Brodke DS, Gollogly S, Alexander MR, Nguyen BK, Dailey AT, Bachus AK. Dynamic cervical plates: biomechanical evaluation of load sharing and stiffness. Spine 2001; 26(12): 1324-29.

2. Goodship V, Jacobs D. Polyvinyl alcohol: materials, procesing and applications, review reports. Rapra Review Reports 2005; 16(12): 3-24.

3. Mazzonetto R, Paza AO, Spagnoli DB. A retrospective evaluation of rigid fixation in orthognathic surgery using a biodegradable self-reinforced (70L: 30DL) polylactide. Int J Oral Maxillofac Surg 2004; 33: 664-9.
4. Wahl DA, Czernuszka JT. Collagen-Hydroxy apatite composites for hard tissue repair. European cells and Materials 2006; 11: 43-56.

5. Suciu AN, Iwatsubo T, Matsuda M. A study upon durability of the artificial knee joint with PVA hydro-gel cartilage. JSME 2004; 47(1): 199-208.

6. Stammen S, Williams JA, Ku DN. Mechanical properties of a novel PVA hydrogel in shear and unconfined compression. Biomaterials 2001; 22: 799-806.

7. Pan YS, Xiong DS, Ma RY. A study on the friction properties of poly(vinyl alcohol) hydrogel as articular cartilage against titanium alloy. Wear 2007; 262: 1021-25.

8. Kobayashi M, Chang YS, Oka M. A two year in vivo study of polyvinyl alcohol-hydrogel (PVA-H) artificial meniscus. Biomaterials 2005; 26: 3243-8.

9. Annie J, Nair MB, Varma HK. Biodegradation and cytocompatibility studies of a triphasic ceramiccoated porous Hydroxy apatite for bone substitute applications. Int J Appl Ceram Technol 2008; 5(1): 11-9.

10. ASTM D 638-99. Standard test method for tensile properties of plastics. An American National Standard 2006, copyright @ ASTM 100 Barr Harbor Drive, West Conshohocken, PA 194282959, United States.

11. ASTM D 790-99. Standard test method for flexural properties of unreinforced plastics and electrical insulating materials, An American National Standard 2006, copyright @ ASTM 100 Barr Harbor Drive, West Conshohocken, PA 19428-2959, United States 